\title{
Empirical rheology of wheat flour doughs with pea, soybean and whey protein isolates
}

\author{
Amanda de Cássia NOGUEIRA ${ }^{1}$ (D), Rafael Kaian do Nascimento de AQUINOํㅜ, Caroline Joy STEEL ${ }^{1 *}(1)$
}

\begin{abstract}
The use of different protein sources in cereal products does not only aim to enrich them with proteins, but also to improve their protein quality, especially concerning the lysine content, the limiting amino acid in wheat flour. As an alternative to enrichment, protein isolates become viable because they provide protein content and quality. However, that the addition of protein sources to wheat flour greatly affects its rheological properties. Thus, the objective of this study was to evaluate the empirical rheology of wheat flour doughs substituted by pea (PPI), soybean (SPI), and whey (WPI) protein isolates, comparing the behavior of these three sources in order to predict the best application. Of all the isolates, PPI seems to have interfered less in the rheological profile of pure flour. WPI caused major changes, while SPI remained intermediate, but closer to PPI. Concentrations of PPI and SPI up to $10 \%$ and WPI up to 5\% did not greatly modify the viscoelastic profile of the dough, which would allow the use of these mixtures in the production of breads, while higher concentrations would be more suitable for the manufacture of molded biscuits, in which the formation of a protein network is not necessary.
\end{abstract}

Keywords: extensograph; farinograph; pea; soybean; whey.

Practical Application: The search for products that provide more than basic nutrition has increased and knowing/predicting/ comparing the behavior of different protein sources is essential to offer great alternatives in this application; since the addition of protein sources to food formulations can affect both the process and the final product, in addition to helping with product development.

\section{Introduction}

Protein enrichment of cereal-based products has been carried out to improve their nutritional properties, increase the consumption of proteins, or compensate their deficiency in certain limiting amino acids such as lysine. Hence, refined wheat flour, as the main ingredient of bakery products, and considering its protein profile, can be improved by adding ingredients and/or raw materials rich in protein (Gani et al., 2015).

Soybean, pea, and whey protein isolates can be alternatives to reach this goal. It is known that they have been studied concerning their functional features, whether technological or physiological. However, since functionality depends on the means in which these proteins are inserted (Foegeding et al., 2011), it is paramount to study their behavior in the product matrix during all stages of the process, in addition to the interaction of the several protein sources (Gani et al., 2015).

The study of empirical rheology of wheat flour doughs is the first step of this more specific study, since it assists in the prediction of the dough processing characteristics and the quality of the final products (Dobraszczyk, 1997; Schmiele et al., 2012) and in the product development process.

The addition of protein isolates tends to change the rheology of the dough, since it causes the dilution of gluten proteins and, consequently, the weakening of the protein network formed by them. There are studies in which authors used these isolates, mainly that of soybean (Ribotta et al., 2005; Singh \& Mohamed, 2007;
Ammar et al., 2011; Tang \& Liu, 2017). However, the comparison between them and the determination of the maximum addition level were not yet reported. Thus, our objective was to evaluate the empirical rheology of wheat flour doughs added with pea, soybean, and whey protein isolates, comparing the behavior of these three sources, in order to define the application of doughs and the need for adjustments in the process.

\section{Material and methods}

\subsection{Material}

Wheat flour (WF) (Moinho Hortolândia, Hortolândia, SP, Brazil) suitable for cookie production, pea protein isolate (PPI) (Nutralys S85F, Labonathus, São Paulo, SP, Brazil), soybean protein isolate (SPI) (SUPRO ${ }^{\circ}$ XT 221D, Solae, São Paulo, SP, Brazil), and whey protein isolate (WPI) (ALIBRA CL 3987, Alibra, Campinas, SP, Brazil).

\subsection{Methods}

\section{Raw material characterization}

The centesimal composition (moisture, crude protein, lipids, and ash) was determined according to the respective AACC International Methods (44-15.02, 46-13.01, 30-25.01 and 08-01.01) (American Association of Cereal Chemistry International, 2010). The total carbohydrate content was calculated by difference. 
Wheat flour was also characterized as for its wet and dry gluten contents and gluten index, and Falling Number, according to AACC International Methods 38-12.02 and 56-81.03, respectively. The hydrogen ion activity $(\mathrm{pH})$ of the samples was determined according to AACC International Method 02-52.01, in a suspension of $10 \mathrm{~g}$ of sample in $100 \mathrm{~g}$ of distilled water.

The amino acids profile was determined using the method described by White et al. (1986) and Hagen et al. (1989). On the other hand, tryptophan content was measured according to Lucas \& Sotelo (1980).

Protein solubility of the samples was determined at $\mathrm{pH}$ from 5 to 8 , according to the method described by Saeed \& Cheryan (1988). Samples (1 $\mathrm{g}$ of flour or $0.5 \mathrm{~g}$ of protein isolate), with addition of $50 \mathrm{~mL}$ of distilled water, were kept for 1 hour at constant stirring, adjusting the $\mathrm{pH}$ during extraction with $\mathrm{NaOH} 0.5 \mathrm{~N}$ or $\mathrm{HCl} 0.5 \mathrm{~N}$. Then, the material was centrifuged at $6,000 \mathrm{xg}$ for $30 \mathrm{~min}$. Total and soluble protein contents were determined by using AACC International Method 46-13.01. Solubility of proteins was determined according to Equation 1. The conversion factors used were 5.70, 5.75, 5.71 and 6.38, for WF, PPI, SPI and WPI, respectively.

Protein solubility in water $=($ Protein in supernatant $/$ Total protein $) \times 100(1)$

Water absorption capacity (WAC) of the samples was determined according to Schmiele (2009). A sample of $2.5 \mathrm{~g}$ (dry basis) was kept in suspension in $30 \mathrm{~mL}$ of distilled water at $25^{\circ} \mathrm{C}$ for $30 \mathrm{~min}$, in conical centrifuge tubes with $50 \mathrm{~mL}$ capacity, in an agitated water bath. The suspension was centrifuged at 2,200 $\mathrm{xg}$ for $10 \mathrm{~min}$ and the supernatant was taken to an oven with air circulation and renovation at $105^{\circ} \mathrm{C}$ for 4 hours. The analysis was performed in triplicate and the results were expressed in percentage. WAC, in \%, was determined according to Equation 2.

$W A C=[($ Centrifugation residue in $g) /($ Sample in $g-$ Evaporation residue in $g)] \times 100(2)$

\section{Empirical rheological characterization of pre-mixes}

Pre-mixes were characterized by the replacement of WF by isolates until the maximum concentration that enabled the farinograph analysis (item 2.2.2.1), without necessary adjustments (except for the extension of the analysis time). Thus, the replacement of WF by isolates accounted for $0,5,10,15,20$, 25 , and $30 \%$. For the extensograph analysis (item 2.2.3.2), the replacement level was lower for SPI (up to 20\%) and WPI (up to $5 \%$ ), since they were the maximum amounts that allowed the removal of the dough from the farinograph for the analysis in the extensograph. On the other hand, for the RVA analysis (2.2.3.3 item), the same concentrations used in the farinograph analysis were kept. Pure wheat flour (control - 0\%) was also analyzed.

\section{Farinograph properties}

Farinograph properties were determined, in triplicate, according to AACC International Method 54-21.01 using a Brabender farinograph (Duisburg, Germany), model 827505, evaluating water absorption (WA), arrival time (AT), dough development time (DDT), stability (S), and mixing tolerance index (MTI). Analysis time was extended when necessary, in order to obtain all parameters.

\section{Extensograph properties}

Extensograph properties were analyzed with a Brabender extensograph (Duisburg, Germany), model 860703, according to AACC International Method 54-10.01. Parameters evaluated were: resistance to extension (R), extensibility (E), and ratio number (D).

\section{Pasting properties}

Pasting properties were determined in Rapid Visco Analyser (RVA) (Perten Instruments, Hägersten, Sweden), using the Thermocline for Windows software, version 2.3 (Jessup, USA) and Standard 1 profile, with $3.5 \mathrm{~g}$ of sample (14\% moisture basis), according to method 162 of International Association for Cereal Science and Technology (1996). The following parameters were evaluated: pasting temperature, peak viscosity, trough or minimum viscosity during heating, final viscosity, breakdown, and setback.

\section{Statistical analysis}

Results were evaluated by calculating the means, standard deviations, analysis of variance (ANOVA), and comparisons between means using the Tukey test $(\mathrm{P} \leq 0.05)$.

\section{Results and discussion}

\subsection{Raw material characterization}

The characterization of raw materials can be observed in Table 1. Wheat flour presented values of moisture and proteins according to what is established by the Brazilian legislation for Type 1 flour (Brasil, 2005), accounting for a maximum of $15 \%$ moisture and at least $7.5 \%$ proteins. However, the ash content was slightly above the limit defined (maximum of $0.8 \%$ ). Given this, its classification is Type 2 .

Pea protein isolate (PPI) featured protein content slightly below the expected value. Karaca et al. (2011) and Lam et al. (2017) found, for different PPIs, protein contents from 81.1 to $92.5 \%$. The ash and lipid values found by these authors, which ranged from 5.6 to $7.3 \%$ and from 2.8 to $3.5 \%$ (dry basis), respectively, were also a little higher than the values of our study.

As PPI, soy protein isolate (SPI) featured protein content slightly lower than the expected value. Some authors also found higher values (from 84.5 to 94.9\%) (Ammar et al., 2011; Dhinda et al., 2012; Lam et al., 2017). However, Karaca et al. (2011), for one of the SPI samples analysed, measured a lower protein content $(72.6 \%)$, as in our study. Lipid content was close to one of the samples of Lam et al. (2017) (1.7\%), as well as the ash content $(6.1 \%)$. This difference of the values may be associated with the pea cultivars or with the protein isolate extraction method (Lam et al., 2017). On the other hand, for whey protein isolate (WPI), the protein content was higher and closer to that mentioned by Lam et al. (2017) (83.5\%) and by Onwulata et al. (2014) (90.1\%). The ash and lipid contents were also close to those observed by Lam et al. (2017) (of 2.9 and $2.6 \%$, respectively). 
Table 1. Characterization of wheat flour (WF) and pea (PPI), soy (SPI) and whey (WPI) protein isolates.

\begin{tabular}{|c|c|c|c|c|}
\hline Parameters & WF & PPI & SPI & WPI \\
\hline Moisture (\%) & $13.52 \pm 0.03$ & $6.22 \pm 0.17$ & $4.88 \pm 0.05$ & $5.22 \pm 0.01$ \\
\hline Protein (\% dry basis) & $11.09 \pm 0.24$ & $69.31 \pm 0.94$ & $79.56 \pm 3.57$ & $86.23 \pm 0.66$ \\
\hline Lipid (\% dry basis) & $2.86 \pm 0.14$ & $2.16 \pm 0, .04$ & $1.60 \pm 0.15$ & $2.38 \pm 0.16$ \\
\hline Ash (\% dry basis) & $1.24 \pm 0.13$ & $3.97 \pm 0.05$ & $5.08 \pm 0.19$ & $2.98 \pm 0.27$ \\
\hline $\begin{array}{l}\text { Total carbohydrates by } \\
\text { difference (\% dry basis) }\end{array}$ & 84.81 & 24.56 & 13.76 & 8.41 \\
\hline Wet gluten (\%) & $25.4 \pm 0.3$ & - & - & - \\
\hline Dry gluten (\%) & $8.5 \pm 0.3$ & - & - & - \\
\hline Gluten index & $97.5 \pm 2.4$ & - & - & - \\
\hline Diastatic activity (s) & $492 \pm 14$ & - & - & - \\
\hline $\mathrm{pH}$ & $6.39 \pm 0.01$ & $7.33 \pm 0.01$ & $7.35 \pm 0.01$ & $6.07 \pm 0.05$ \\
\hline WAC (\%) & $222 \pm 4$ & $620 \pm 29$ & $527 \pm 4$ & $445 \pm 57$ \\
\hline Protein solubility - pH 5 & $20.15 \pm 2.20$ & $6.62 \pm 0.86$ & $26.90 \pm 0.54$ & $87.26 \pm 0.82$ \\
\hline Protein solubility - pH 6 & $17.77 \pm 1.11$ & $13.35 \pm 0.81$ & $45.99 \pm 2.27$ & $93.36 \pm 1.51$ \\
\hline Protein solubility - $\mathrm{pH} 7$ & $16.24 \pm 2.54$ & $16.01 \pm 0.04$ & $48.92 \pm 1.21$ & $86.05 \pm 6.78$ \\
\hline Protein solubility - $\mathrm{pH} 8$ & $41.80 \pm 4.43$ & $26.20 \pm 2.15$ & $52.59 \pm 1.37$ & $91.90 \pm 2.03$ \\
\hline
\end{tabular}

Averages \pm standard deviations. WF: wheat flour; PPI: pea protein isolate; SPI: soy protein isolate; WPI: whey protein isolate; WAC: water absorption capacity.

The $\mathrm{pH}$ values of PPI and SPI were very close to each other and higher than wheat flour (WF), whereas WPI featured $\mathrm{pH}$ closer to that of the flour. However, all remained close to neutrality.

The amino acids profile of raw materials is presented in Table 2. A great difference in the content of most amino acids of WF and isolates was verified, which justifies the use of these ingredients for enriching wheat flour-based products. Among the amino acids of PPI, glutamic acid, aspartic acid, lysine, leucine and arginine can be highlighted. Stone et al. (2014) also highlighted the contents of these amino acids in PPIs from different cultivars and extraction methods. In addition to these amino acids, PPI is also a source of branched-chain amino acids (BCAA) such as leucine, isoleucine, and valine (Coutinho et al., 2014). In our study, BCAA content of PPI accounted for $20.08 \mathrm{~g} / 100 \mathrm{~g}$ protein.

SPI also presented the essential amino acids, such as leucine, lysine, valine, isoleucine, and threonine. Mohsen et al. (2009) also highlighted these amino acids in SPI. Despite good contents of lysine for PPI and SPI, both have low contents of sulfur-containing amino acids, such as methionine and cystine, which is characteristic of legumes (Rockland \& Radke, 1981; Ampe et al., 1986; Pereira \& Oliveira, 2004). According to Gruber et al. (2005), compared with soybean, pea proteins have higher levels of lysine, but lower contents of sulfur-containing amino acids; which was also observed in our study.

As for the amino acid composition of WPI, it can be considered excellent, since it contains all essential amino acids for humans (Ziegler \& Sgarbieri, 2009) in adequate quantities. It is worth mentioning the contents of lysine and threonine, in addition to the high content of BCCA (25.72), corresponding to the contents of valine, leucine, and isoleucine. This result is close to that mentioned by Etzel (2004), of approximately 25\% BCCA in WPI.

Regarding the contents of lysine, limiting amino acid in WF, all isolates contain it in significant quantities: PPI features approximately $70 \%$ more; SPI, $60 \%$ more; and WPI, $75 \%$ more.
Table 2. Amino acid profile of the wheat flour (WF) and pea (PPI), soy (SPI) and whey (WPI) protein isolates.

\begin{tabular}{|c|c|c|c|c|}
\hline $\begin{array}{c}\text { Amino acids } \\
(\mathrm{g} / 100 \mathrm{~g} \text { protein })\end{array}$ & WF & PPI & SPI & WPI \\
\hline \multicolumn{5}{|c|}{ Hydrophobic (non-polar) } \\
\hline Glycine & 3.70 & 4.44 & 4.32 & 1.93 \\
\hline Alanine & 3.25 & 4.86 & 4.58 & 5.83 \\
\hline Proline & 10.37 & 4.72 & 5.33 & 6.59 \\
\hline Valine & 4.24 & 5.66 & 5.12 & 6.49 \\
\hline Leucine & 6.58 & 9.08 & 8.11 & 11.65 \\
\hline Isoleucine & 3.61 & 5.35 & 5.09 & 7.57 \\
\hline Methionine & 1.44 & 1.11 & 1.42 & 2.59 \\
\hline \multicolumn{5}{|l|}{ Aromatic } \\
\hline Phenylalanine & 4.60 & 6.07 & 5.48 & 3.44 \\
\hline Tyrosine & 2.89 & 3.79 & 3.65 & 3.12 \\
\hline Tryptophan & 2.07 & 0.65 & 1.17 & 2.23 \\
\hline \multicolumn{5}{|l|}{ Polar (uncharged) } \\
\hline Serine & 4.78 & 6.20 & 5.68 & 5.89 \\
\hline Threonine & 2.89 & 4.26 & 4.20 & 8.29 \\
\hline Cystine & 1.26 & 1.23 & 1.14 & 1.96 \\
\hline \multicolumn{5}{|l|}{ Positively charged } \\
\hline Lysine & 2.80 & 9.13 & 7.06 & 11.34 \\
\hline Arginine & 5.14 & 9.03 & 7.49 & 2.24 \\
\hline Histidine & 2.07 & 3.13 & 3.07 & 2.16 \\
\hline \multicolumn{5}{|l|}{ Negatively charged } \\
\hline Aspartic acid & 4.42 & 15.50 & 13.76 & 14.45 \\
\hline Glutamic acid & 31.38 & 20.08 & 19.52 & 19.68 \\
\hline
\end{tabular}

WF: wheat flour; PPI: pea protein isolate; SPI: soy protein isolate; WPI: whey protein isolate.

In relation to protein solubility, the highest value was observed for WPI in all $\mathrm{pH}$ values (from 5 to 8 ), followed by SPI (Table 1). On the other hand, PPI, in addition to presenting the lowest solubility values between the isolates, was less soluble than WF, except at $\mathrm{pH} 7$, when the values were similar. Lam et al. (2017) observed values of protein solubility at $\mathrm{pH} 7$ close to 
our study. Reinkensmeier et al. (2015) observed low protein solubility for PPI at pH 4-11 (approximately 10\%), which may result from acidic extraction and isoelectric precipitation that, in turn, influence protein conformation.

The water absorption capacity (WAC) of isolates was higher than that of WF (Table 1), and among them, PPI presented the greatest WAC $(620 \pm 29 \%)$, followed by SPI $(527 \pm 4 \%)$ and WPI (445 $\pm 57 \%)$. According to Swanson (1990), the severity of the heat treatment may cause an increase in the WAC. This explains the diversity of values found in the literature. On the other hand, PPI and SPI, with greater WAC than WF (222 $\pm 4 \%)$, tend to compete for the existing water, requiring greater water addition for the formation of the dough.

\subsection{Rheological characterization of pre-mixes}

\section{Farinograph properties}

The results obtained in the farinograph analysis are presented in Table 3.

PPI

Water absorption (WA) increased with the addition of PPI, as well as the arrival time (AT). Up to $10 \%$, AT values did not change, and at larger concentrations (20, 25, and 30\%) were higher and similar. The great water absorption capacity of PPI $(620 \pm 5 \%)$ was probably responsible for its higher farinograph
WA. Even considering the higher WA, it was possible to observe a delay in hydration (higher values of AT), since PPI, when competing for water, hindered the water binding to gluten proteins and, consequently, the development of the gluten network. In addition, there was a greater dilution of gluten at higher isolate concentrations. According to Schmiele et al. (2017), a longer time for hydration of gluten proteins is expected when other proteins are mixed with water and subjected to mechanical shear.

Dough development time (DDT) did not change at a concentration of $5 \%$, but increased at other concentrations, nearly doubling at $30 \%$ (15 $\mathrm{min}$ ) in relation to WF (7.7 $\mathrm{min})$. On the other hand, stability $(S)$ increased at concentrations of 5 and $10 \%$, decreasing at larger concentrations, with a sudden drop at concentrations of 25 and $30 \%$, compared to the control (from 14.4 to approximately $6.6 \mathrm{~min}$ ). Mixing tolerance index (MTI) remained unchanged up to $15 \%$, and increased at other replacement levels. The increase in DDT and decrease in S demonstrate the delay in the formation of the gluten network and, also, its weakening, with the presence of the isolates. Protein isolates can interfere in several interactions in wheat flour doughs and, thus, avoid the total hydration of gluten proteins, interfering in dough development (Zadow, 1981; Schmiele et al., 2015).

Hence, the replacement of WF by up to $10 \%$ of PPI did not significantly alter the characteristics of the dough, and there was also a gain in water absorption. At other concentrations, however, an increase in AT and DDT, and a decrease in stability were noted, changing the characteristics of the dough.

Table 3. Farinograph parameters of pure wheat flour and with different levels of substitution of wheat flour by pea (PPI), soy (SPI) and whey protein (WPI) isolates.

\begin{tabular}{|c|c|c|c|c|c|c|}
\hline \multicolumn{2}{|c|}{ Level of substitution of WF } & \multirow{2}{*}{$\frac{\text { WA (\%) }}{61.4 \pm 0.2^{\mathrm{g}}}$} & \multirow{2}{*}{$\frac{\mathrm{AT}(\min )}{1.5 \pm 0.1^{\mathrm{c}}}$} & \multirow{2}{*}{$\begin{array}{c}\text { DDT (min) } \\
7.7 \pm 0.3^{\mathrm{d}}\end{array}$} & \multirow{2}{*}{$\frac{S(\min )}{14.4 \pm 0.6^{b c}}$} & \multirow{2}{*}{$\frac{\text { MTI (BU) }}{28 \pm 3^{\mathrm{bcd}}}$} \\
\hline PPI & 0 & & & & & \\
\hline & 5 & $64.9 \pm 0.2^{\mathrm{fA}}$ & $1.3 \pm 0.1^{\mathrm{cA}}$ & $8.9 \pm 0.4 \mathrm{dNS}$ & $18.9 \pm 0.1 \mathrm{aA}$ & $13 \pm 3 \mathrm{~dB}$ \\
\hline & 10 & $70.4 \pm 0.5^{\mathrm{eA}}$ & $2.1 \pm 0.1^{\mathrm{cA}}$ & $11.7 \pm 0.9 \mathrm{cNs}$ & $16.7 \pm 1.3 \mathrm{abA}$ & $20 \pm 0^{\mathrm{cdB}}$ \\
\hline & 15 & $76.8 \pm 0.8^{\mathrm{dA}}$ & $6.8 \pm 0.6^{\mathrm{bB}}$ & $13.8 \pm 1.0^{\mathrm{bcA}}$ & $13.2 \pm 0.2^{\mathrm{cA}}$ & $20 \pm 0^{\mathrm{cdC}}$ \\
\hline & 20 & $82.9 \pm 0.7^{\mathrm{cA}}$ & $9.6 \pm 0.3 \mathrm{aB}$ & $16.9 \pm 0.8^{\mathrm{aA}}$ & $10.3 \pm 0 ., 2 \mathrm{dA}$ & $43 \pm 12^{\mathrm{abB}}$ \\
\hline & 25 & $88.7 \pm 0.9^{\mathrm{bA}}$ & $10.2 \pm 0.4^{\mathrm{aB}}$ & $14.2 \pm 0.9^{\mathrm{bA}}$ & $6.3 \pm 0.7^{\mathrm{eA}}$ & $48 \pm 10^{\mathrm{aA}}$ \\
\hline \multirow[t]{7}{*}{ SPI } & 0 & $61.4 \pm 0.2^{g}$ & $1.5 \pm 0.1^{\mathrm{d}}$ & $7.7 \pm 0.3^{b c}$ & $14.4 \pm 0.6^{\mathrm{a}}$ & $28 \pm 3^{a b c}$ \\
\hline & 5 & $63.2 \pm 0.5^{\mathrm{fB}}$ & $1.3 \pm 0.0^{\mathrm{dA}}$ & $9.3 \pm 0.4^{\mathrm{abNS}}$ & $13.4 \pm 1.0 \mathrm{aB}$ & $35 \pm 0 \mathrm{abA}$ \\
\hline & 10 & $65.6 \pm 0.3$ ев & $1.4 \pm 0.1 \mathrm{dA}$ & $10.7 \pm 1.0$ aNs & $14.0 \pm 0.9$ ав & $28 \pm 4^{\mathrm{abcAB}}$ \\
\hline & 15 & $68.8 \pm 0.4^{\mathrm{dB}}$ & $2.4 \pm 0.4^{\mathrm{cC}}$ & $10.9 \pm 0.7^{\mathrm{aB}}$ & $11.0 \pm 0.2^{\mathrm{bB}}$ & $42 \pm 3^{\mathrm{aB}}$ \\
\hline & 20 & $72.5 \pm 0.4^{\mathrm{cB}}$ & $4.5 \pm 0.3^{\mathrm{bC}}$ & $10.6 \pm 0.5^{\mathrm{aC}}$ & $8.6 \pm 0.2 \mathrm{cB}$ & $23 \pm 8^{\mathrm{bcB}}$ \\
\hline & 25 & $77.0 \pm 0.4^{\mathrm{bB}}$ & $5.5 \pm 0.4 \mathrm{aC}$ & $7.0 \pm 0.1^{\mathrm{cB}}$ & $5.5 \pm 0.6^{\mathrm{dAB}}$ & $19 \pm 10^{\mathrm{bcB}}$ \\
\hline & 30 & $80.1 \pm 0.2^{\mathrm{aB}}$ & $4.8 \pm 0.3^{\mathrm{abB}}$ & $6.5 \pm 0.9^{\mathrm{cB}}$ & $2.8 \pm 0.6^{\mathrm{eB}}$ & $17 \pm 6^{\mathrm{cB}}$ \\
\hline \multirow[t]{7}{*}{ WPI } & 0 & $61.4 \pm 0.2^{\mathrm{a}}$ & $1.5 \pm 0.1^{\mathrm{a}}$ & $7.7 \pm 0.3^{c}$ & $14.4 \pm 0.6^{\mathrm{a}}$ & $28 \pm 3^{d}$ \\
\hline & 5 & $56.7 \pm 0.2^{\mathrm{bC}}$ & $5.8 \pm 0.4^{\mathrm{bB}}$ & $8.6 \pm 0.2^{\mathrm{cNS}}$ & $5.3 \pm 0.3^{\mathrm{bcC}}$ & $38 \pm 3^{\mathrm{dA}}$ \\
\hline & 10 & $53.8 \pm 0.1^{\mathrm{cC}}$ & $9.0 \pm 0.6^{\mathrm{cB}}$ & $11.5 \pm 0.6^{\mathrm{bNS}}$ & $5.9 \pm 0.1 \mathrm{bC}$ & $36 \pm 7 \mathrm{dA}$ \\
\hline & 15 & $50.9 \pm 0.1 \mathrm{dC}$ & $11.9 \pm 0.2^{\mathrm{abA}}$ & $14.2 \pm 0.2^{\mathrm{aA}}$ & $4.6 \pm 0.2^{\mathrm{cdC}}$ & $73 \pm 12^{\mathrm{abA}}$ \\
\hline & 20 & $49.7 \pm 0.4^{\mathrm{eC}}$ & $12.2 \pm 1.2^{\mathrm{abA}}$ & $14.4 \pm 1.4 \mathrm{aB}$ & $4.0 \pm 0.2 \mathrm{dC}$ & $83 \pm 6^{\mathrm{aA}}$ \\
\hline & 25 & $48.5 \pm 0.1^{\mathrm{fC}}$ & $13.1 \pm 0.3^{\mathrm{aA}}$ & $15.3 \pm 0.7^{\mathrm{aA}}$ & $4.3 \pm 0.4 \mathrm{~dB}$ & $60 \pm 0^{\mathrm{bA}}$ \\
\hline & 30 & $48.1 \pm 0.4^{\mathrm{fC}}$ & $11.0 \pm 1.3^{\mathrm{bcA}}$ & $13.4 \pm 1.4^{\mathrm{abA}}$ & $4.5 \pm 0.2^{\mathrm{CdAB}}$ & $73 \pm 12^{\mathrm{abA}}$ \\
\hline
\end{tabular}

Averages \pm standard deviations. WF: wheat flour; PPI: pea protein isolate; SPI: soy protein isolate; WPI: whey protein isolate; WA: water absorption; AT: arrival time; DDT: dough development time; S: stability; MTI: mixing tolerance index; BU: Brabender units. Means with lowercase and different letters in the same column for each isolate differ statistically from each other $(\mathrm{P} \leq 0.05)$. Averages with capital letters for the same replacement levels differ statistically from each other $(\mathrm{P} \leq 0.05)$. 
SPI

WA increased with SPI addition and, for AT, up to $10 \%$ SPI, values were similar, with an increase at higher concentrations. However, similar values at concentrations of 20,25 , and $30 \%$ were also observed. DDT, at concentrations of 5, 25, and 30\% was similar to WF, and an increase at intermediate concentrations (10, 15 , and $20 \%$ ) was observed. Stability (S) remained unchanged up to $10 \%$, with a decrease in the subsequent concentrations. From $20 \%$, values had a very abrupt fall. On the other hand, MTI values did not change in relation to WF.

Changes observed in WA were similar to those observed with the addition of PPI, probably due to the high WAC of SPI $(527 \pm 4 \%)$. An increase in AT was found, but it was lower than with PPI. Thus, SPI may have interfered less in the hydration of gluten proteins (WAC of SPI was lower than PPI), thus achieving a slightly faster hydration. This hydration can also explain the increase in DDT followed by a decrease. However, stability was also affected, causing the same weakening. However, stability was also affected, causing the same weakening. The increase in DDT and the maintenance of stability values up to the concentrations of 20 and $10 \%$, respectively, can be attributed to the aggregation of soybean proteins that leads to a greater water binding capacity in the system and increases the mechanical tolerance of the dough (Crockett et al., 2011). Tang \& Liu (2017) also observed an increase in WA and DDT by adding up to $30 \%$ soybean proteins.

Similarly to PPI, adding up to $10 \%$ of SPI did not change the characteristics of the dough, except for the WA. Apparently, doughs with SPI, when compared to PPI, seem to suffer interactions more quickly, resulting in a more pronounced weakening at these higher concentrations.

\section{WPI}

Differently to previously discussed isolates, WPI decreased WA. This behavior is probably linked to the lower capacity of WPI to absorb water ( $445 \pm 57 \%)$, compared to the other isolates studied, and related to the fact that WPI has a higher content of hydrophobic amino acids than PPI and SPI. In relation to AT, the values increased with WF replacement by WPI, causing a significant change in this parameter already at 5\%. Values remained close at concentrations above $15 \%$. DDT value at 5\% did not differ from WF. It increased at other concentrations, a behavior similar to the other isolates. Stability decreased at all concentrations, with a sharp decrease (from 4.0 to $5.9 \mathrm{~min}$ ) in relation to the control (14.4 $\mathrm{min})$. Assay with concentrations between 15 and 30\% showed similar values. MTI values remained unchanged up to $10 \%$ WPI, increasing at other concentrations. The reduction in stability, as well as the increase in MTI, reflected in a major weakening of the dough. And, unlike pea and soybean isolates, weakening was verified with $5 \%$ addition, considerably changing dough stability. Adding up to $30 \%$ whey proteins, Tang \& Liu (2017) observed similar results: a decrease in WA and an increase in DDT, in addition to a decrease in stability, in relation to pure WF. According to these authors, the addition of proteins leads to a complex system, delaying the hydration and the elongation/alignment of gluten (increase in DDT) and decreasing its stability, due to dilution and interference in the network.
Regardless of the isolate used, the weakening of the dough was verified as the protein-based products were being incorporated and among these three isolates, PPI proved to be the one that least interfered with the profile of pure flour. On the other hand, WPI caused major changes, whereas SPI remained intermediate, although closer to PPI.

\section{Extensograph properties}

In Table 4, the extensograph parameters can be observed. It was not possible to measure resistance (R) for assays with additions of 20,25 , and $30 \%$ PPI and 15, 20, 25, and 30\% SPI, since this parameter is defined as the measurement on the $\mathrm{y}$-axis (resistance) at $50 \mathrm{~mm}$, and, for these assays, extensibility (x-axis) did not reach $50 \mathrm{~mm}$. Consequently, the ratio number $(\mathrm{D}=\mathrm{R} / \mathrm{E})$ could not be calculated. However, a great alteration of the dough was verified with these additions. For WPI, the analysis was conducted up to an addition of 5\%. Other additions caused changes in the dough which prevented us from analyzing it. After preparing the dough in the farinograph, the dough was very fluid, and its removal from the equipment for cutting and subsequent extension was not possible.

\section{PPI}

Extensibility (E) decreased with the increase of PPI in comparison to pure WF; on the other hand, resistance (R) and ratio number $(\mathrm{D})$ increased. Despite this increase, a great alteration of the dough (extremely sticky dough, difficult to mold, with no elasticity - to the extent that R was not measured with 20\%) was verified. Thus, from 10\% PPI, the characteristics of the dough were considerably modified. At times of 45 and $135 \mathrm{~min}$, curves featured a very similar profile, demonstrating that major changes were not noticed during the resting period of the dough.

\section{SPI}

For the three analysis times (45, 90 and $135 \mathrm{~min})$, the behavior was the same with the addition of PPI. Extensibility decreased with the addition of SPI in comparison to pure WF, with a greater decrease when compared to PPI. Over time, R and $\mathrm{D}$ increased, whereas E decreased, except at a concentration of $20 \%$, in which it practically did not change. Despite the increase in resistance and decrease in extensibility, both with PPI and SPI, compared to pure WF, observed a weakening of the dough, considering the consistency of the dough obtained (the dough was increasingly sticky, losing its desired viscoelastic properties).

\section{WPI}

At $45 \mathrm{~min}$, the addition of 5\% WPI did not change any of the parameters. For the other analysis times (90 and 135 $\mathrm{min})$, it increased resistance (R) and the ratio number (D). Extensibility (E), however, did not change when compared to pure WF. Therefore, there was an apparent strengthening of the dough at this concentration, due to an increase in resistance and a slight decrease in extensibility. Madenci \& Bilgiçli (2014) also observed this behavior when adding 4 and $8 \%$ of whey protein concentrate, as well as Indrani et al. (2007) using 5, 10, 15\% of the same ingredient. However, higher concentrations affected 
Table 4. Extensograph parameters of pure wheat flour and with different levels of substitution of wheat flour by pea (PPI), soy (SPI) and whey protein (WPI) isolates.

\begin{tabular}{|c|c|c|c|c|c|c|c|c|c|c|}
\hline \multirow{2}{*}{ Times } & \multirow{2}{*}{$\begin{array}{c}\text { Level of } \\
\text { substitution } \\
\text { of WF (\%) }\end{array}$} & $\mathrm{R}(\mathrm{BU})$ & $\mathrm{E}(\mathrm{mm})$ & $\mathrm{D}(\mathrm{R} / \mathrm{E})$ & $\mathrm{R}(\mathrm{BU})$ & $\mathrm{E}(\mathrm{mm})$ & $\mathrm{D}(\mathrm{R} / \mathrm{E})$ & $\mathrm{R}(\mathrm{BU})$ & $\mathrm{E}(\mathrm{mm})$ & $\mathrm{D}(\mathrm{R} / \mathrm{E})$ \\
\hline & & \multicolumn{3}{|c|}{ PPI } & \multicolumn{3}{|c|}{ SPI } & \multicolumn{3}{|c|}{ WPI } \\
\hline \multirow[t]{7}{*}{$45 \mathrm{~min}$} & 0 & $309 \pm 23^{c}$ & $162 \pm 9^{a}$ & $1.9 \pm 0.3^{\mathrm{d}}$ & $309 \pm 23^{b}$ & $162 \pm 9^{a}$ & $1.9 \pm 0.3 c$ & $309 \pm 23^{\text {ns }}$ & $162 \pm 9^{\text {ns }}$ & $1.9 \pm 0.3^{\mathrm{ns}}$ \\
\hline & 5 & $379 \pm 11^{\mathrm{bA}}$ & $130 \pm 2^{\mathrm{bB}}$ & $2.9 \pm 0.1^{\mathrm{cB}}$ & $405 \pm 14^{\mathrm{aA}}$ & $106 \pm 7^{\mathrm{bC}}$ & $3.9 \pm 0.4^{\mathrm{bA}}$ & $305 \pm 57^{\mathrm{nsB}}$ & $166 \pm 5^{\mathrm{nsA}}$ & $1.9 \pm 0.3^{\mathrm{nsC}}$ \\
\hline & 10 & $438 \pm 13^{\mathrm{aA}}$ & $99 \pm 2^{\mathrm{cA}}$ & $4.4 \pm 0.2^{\mathrm{bB}}$ & $378 \pm 3^{\mathrm{aB}}$ & $75 \pm 6^{\mathrm{cB}}$ & $5.1 \pm 0.3^{\mathrm{aA}}$ & - & - & - \\
\hline & 15 & $423 \pm 14^{\mathrm{a}}$ & $61 \pm 3^{\mathrm{dA}}$ & $6.9 \pm 0.2^{\mathrm{a}}$ & - & $57 \pm 1^{\mathrm{dB}}$ & - & - & - & - \\
\hline & 20 & - & $51 \pm 3^{\mathrm{eNS}}$ & - & - & $47 \pm 2^{\mathrm{dNS}}$ & - & - & - & - \\
\hline & 25 & - & $51 \pm 4^{\mathrm{e}}$ & - & - & - & - & - & - & - \\
\hline & 30 & - & $40 \pm 3^{\mathrm{f}}$ & - & - & - & - & - & - & - \\
\hline \multirow[t]{7}{*}{$90 \mathrm{~min}$} & 0 & $379 \pm 11^{\mathrm{c}}$ & $154 \pm 7^{\mathrm{a}}$ & $2.5 \pm 0.1^{\mathrm{d}}$ & $379 \pm 11^{\mathrm{b}}$ & $154 \pm 7^{\mathrm{a}}$ & $2.5 \pm 0.1^{c}$ & $379 \pm 11^{\mathrm{b}}$ & $154 \pm^{\mathrm{ns}}$ & $2.5 \pm 0.1^{\mathrm{b}}$ \\
\hline & 5 & $435 \pm 25^{\mathrm{bB}}$ & $121 \pm 5^{\mathrm{bB}}$ & $3.6 \pm 0.3^{\mathrm{cB}}$ & $466 \pm 36^{\mathrm{aBA}}$ & $102 \pm 6^{\mathrm{bC}}$ & $4.6 \pm 0.4^{\mathrm{bA}}$ & $507 \pm 21^{\mathrm{aA}}$ & $145 \pm 7^{\mathrm{nsA}}$ & $3.5 \pm 0.3^{\mathrm{aB}}$ \\
\hline & 10 & $512 \pm 32^{\mathrm{aA}}$ & $92 \pm 5^{\mathrm{cA}}$ & $5.5 \pm 0.1^{\mathrm{bNS}}$ & $397 \pm 16^{\mathrm{bB}}$ & $73 \pm 3^{\mathrm{cB}}$ & $5.5 \pm 0.3^{\mathrm{aNS}}$ & - & - & - \\
\hline & 15 & $471 \pm 21^{\mathrm{ab}}$ & $65 \pm 5^{\mathrm{dA}}$ & $7.2 \pm 0.3^{\mathrm{a}}$ & - & $57 \pm 4^{\mathrm{dB}}$ & - & - & - & - \\
\hline & 20 & - & $52 \pm 3^{\text {eNS }}$ & - & - & $49 \pm 5^{\mathrm{dNS}}$ & - & - & - & - \\
\hline & 25 & - & $53 \pm 3^{\mathrm{e}}$ & - & - & - & - & - & - & - \\
\hline & 30 & - & $40 \pm 4^{\mathrm{f}}$ & - & - & - & - & - & - & - \\
\hline \multirow[t]{7}{*}{$135 \mathrm{~min}$} & 0 & $380 \pm 13^{c}$ & $154 \pm 6^{a}$ & $2.5 \pm 0.1^{\mathrm{d}}$ & $380 \pm 13^{\mathrm{b}}$ & $154 \pm 6^{\mathrm{a}}$ & $2.5 \pm 0.1^{\mathrm{c}}$ & $380 \pm 13 b$ & $154 \pm 6^{\mathrm{ns}}$ & $2.5 \pm 0.1^{\mathrm{b}}$ \\
\hline & 5 & $477 \pm 35^{\text {bB }}$ & $124 \pm 6^{\mathrm{bB}}$ & $3.9 \pm 0.3^{\mathrm{cB}}$ & $465 \pm 7^{\mathrm{aB}}$ & $98 \pm 3^{\mathrm{bC}}$ & $4.8 \pm 0.2^{\mathrm{bA}}$ & $548 \pm 26^{\mathrm{aA}}$ & $146 \pm 8^{\mathrm{nsA}}$ & $3.8 \pm 0.2^{\mathrm{aB}}$ \\
\hline & 10 & $562 \pm 27^{\mathrm{aA}}$ & $89 \pm 4^{\mathrm{cA}}$ & $6.3 \pm 0.5^{\mathrm{bNs}}$ & $373 \pm 34^{\mathrm{bB}}$ & $67 \pm 4^{\mathrm{cB}}$ & $5.6 \pm 0.4^{\mathrm{aNS}}$ & - & - & - \\
\hline & 15 & $446 \pm 43^{\mathrm{b}}$ & $60 \pm 4^{\mathrm{dA}}$ & $7.5 \pm 0.4^{\mathrm{a}}$ & - & $55 \pm 2^{\mathrm{dB}}$ & - & - & - & - \\
\hline & 20 & - & $53 \pm 4^{\mathrm{dNS}}$ & - & - & $49 \pm 3^{\mathrm{dNS}}$ & - & - & - & - \\
\hline & 25 & - & $52 \pm 3^{\mathrm{de}}$ & - & - & - & - & - & - & - \\
\hline & 30 & - & $43 \pm 2 \mathrm{e}$ & - & - & - & - & - & - & - \\
\hline
\end{tabular}

Averages \pm standard deviations. WF: wheat flour; PPI: pea protein isolate; SPI: soy protein isolate; WPI: whey protein isolate; R: resistance to extension; E: extensibility; D: ratio R/E $\mathrm{Bu}$ : Brabender Units. Means with lowercase and different letters in the same column a for each isolate differ statistically from each other $(\mathrm{P} \leq 0.05)$. Averages with capital letters for the same replacement levels differ statistically from each other $(\mathrm{P} \leq 0.05)$. NS, ns: no significant.

the dough, making it extremely fluid, not permitting its removal from the farinograph to the extensograph to be modeled and analyzed. According to Zadow (1981), the weakening of wheat flour dough is due to the interference of sulfhydryl groups of whey protein concentrate (WPC) in normal reactions of the sulfhydryl/ disulfide exchange that occur during the development of wheat flour dough. This can be verified considering the impossibility of conducting the extensograph analysis at higher concentrations, because of the inadequate consistency obtained.

\section{Pasting properties}

The pasting properties of the pre-mixes are presented in Table 5.

PPI

Replacing WF by PPI did not alter the pasting temperature, which remained between 86.7 and $87.7^{\circ} \mathrm{C}$. On the other hand, there was a decrease in the values of the other parameters (peak, trough, and final viscosity, breakdown, setback, and peak time) with the replacement.

SPI

Regarding pasting temperature, no assay differed from WF and, among replacements, the $5 \%$ assay differed from those with
15,20 , and $25 \%$. Despite this, values were very close (from 86.4 to $88.9^{\circ} \mathrm{C}$ ). Thus, as for PPI, all other parameters decreased with the addition of SPI.

\section{WPI}

The behavior of WPI was similar to that of the other isolates. Pasting temperature of WPI differed for 10 and 30\% of replacement, but these assays did not differ from the others. The values of this parameter remained with little variation (from 86.7 to $88.6^{\circ} \mathrm{C}$ ). As for the others isolates, the remaining parameters also had a decrease in their values. Indrani et al. (2007) and Sudha et al. (2011) also observed similar results using whey protein concentrate The reduction of viscosity parameters caused by the isolates is probably due to the dilution of starch in the mixtures and to their influence in viscosity. The decrease in setback may be considered positive, since it indicates that isolates possibly have an anti-staling effect, which is desirable in products such as breads and cakes (Schmiele et al., 2017). However, it is necessary to complement this information with a baking test.

When comparing the behavior of the isolates, PPI was the one that least interfered in pasting parameters of WF, due to its highest values. And, regarding setback, which could be related to staling in bakery products, WPI proved to be more effective, reaching lower values compared to other isolates. 
Table 5. Pasting properties of pure wheat flour and with different levels of substitution of wheat flour by pea (PPI), soy (SPI) and whey protein (WPI) isolates.

\begin{tabular}{|c|c|c|c|c|c|c|c|c|}
\hline \multicolumn{2}{|c|}{$\begin{array}{c}\text { Level of } \\
\text { substitution } \\
\text { of WF }(\%)\end{array}$} & \multirow{2}{*}{$\begin{array}{c}\begin{array}{c}\text { Pasting } \\
\text { temperature }\left({ }^{\circ} \mathrm{C}\right)\end{array} \\
87.0 \pm 0.5^{\text {ns }}\end{array}$} & \multirow{2}{*}{$\begin{array}{c}\begin{array}{c}\text { Maximum } \\
\text { viscosity }(c P)\end{array} \\
2266 \pm 34^{\mathrm{a}}\end{array}$} & \multirow{2}{*}{$\begin{array}{c}\begin{array}{c}\text { Trough viscosity } \\
(\mathrm{cP})\end{array} \\
1361 \pm 12^{\mathrm{a}}\end{array}$} & \multirow{2}{*}{$\begin{array}{c}\begin{array}{c}\text { Breakdown } \\
(\mathrm{cP})\end{array} \\
905 \pm 45^{\mathrm{a}}\end{array}$} & \multirow{2}{*}{$\begin{array}{c}\text { Final viscosity } \\
(\mathrm{cP})\end{array}$} & \multirow{2}{*}{$\begin{array}{c}\begin{array}{c}\text { Setback } \\
(\mathrm{cP})\end{array} \\
1246 \pm 10^{\mathrm{a}}\end{array}$} & \multirow{2}{*}{$\begin{array}{c}\begin{array}{c}\text { Peak time } \\
(\mathrm{min})\end{array} \\
6.1 \pm 0.0^{\mathrm{a}}\end{array}$} \\
\hline & 0 & & & & & & & \\
\hline \multirow{5}{*}{ PPI } & 10 & $87.2 \pm 0.0^{\mathrm{nsNS}}$ & $2034 \pm 24^{\mathrm{cA}}$ & $1200 \pm 16^{\mathrm{cA}}$ & $835 \pm 9^{\mathrm{bA}}$ & $2250 \pm 27^{\mathrm{cA}}$ & $1050 \pm 27^{\mathrm{bcA}}$ & $5.9 \pm 0.0^{\mathrm{bNS}}$ \\
\hline & 15 & $87.4 \pm 0.4^{\mathrm{nsNS}}$ & $1886 \pm 28 \mathrm{dA}$ & $1133 \pm 19 \mathrm{dA}$ & $753 \pm 9^{\mathrm{cA}}$ & $2152 \pm 44^{\mathrm{dA}}$ & $1020 \pm 25^{\mathrm{cA}}$ & $5.8 \pm 0.0^{\mathrm{cA}}$ \\
\hline & 20 & $87.2 \pm 0.0^{\mathrm{nsB}}$ & $1631 \pm 31^{\mathrm{eA}}$ & $992 \pm 24^{\mathrm{eA}}$ & $639 \pm 8^{d A}$ & $1900 \pm 35^{\mathrm{eA}}$ & $908 \pm 14^{\mathrm{dA}}$ & $5.9 \pm 0.0 \mathrm{dNS}$ \\
\hline & 30 & $87.7 \pm 1.0^{\mathrm{nsNS}}$ & $1191 \pm 34^{\mathrm{gA}}$ & $707 \pm 20^{\mathrm{gA}}$ & $483 \pm 14^{\mathrm{fA}}$ & $1370 \pm 21^{\mathrm{gA}}$ & $662 \pm 2^{\mathrm{fA}}$ & $5.4 \pm 0.1^{\mathrm{eNS}}$ \\
\hline & 0 & $87.0 \pm 0.5^{\mathrm{ac}}$ & $2266 \pm 34^{\mathrm{a}}$ & $1361 \pm 12^{a}$ & $905 \pm 45^{\mathrm{a}}$ & $2607 \pm 22^{a}$ & $1246 \pm 10^{\mathrm{a}}$ & $6.1 \pm 0.0^{\mathrm{a}}$ \\
\hline \multirow[t]{3}{*}{ SPI } & 5 & $86.4 \pm 0.1^{\mathrm{cNS}}$ & $2088 \pm 14^{\text {bB }}$ & $1221 \pm 17^{\mathrm{bA}}$ & $868 \pm 14^{\mathrm{aA}}$ & $2371 \pm 7^{\mathrm{bA}}$ & $1150 \pm 10^{\mathrm{bNS}}$ & $6.0 \pm 0.0^{\mathrm{bNS}}$ \\
\hline & 10 & $87.3 \pm 0.9^{\mathrm{abcNS}}$ & $1806 \pm 16^{\mathrm{cB}}$ & $1087 \pm 5^{\mathrm{cB}}$ & $719 \pm 19^{\text {ьв }}$ & $2154 \pm 13^{\mathrm{cB}}$ & $1066 \pm 10^{\mathrm{cB}}$ & $5.8 \pm 0.1$ bcNS \\
\hline & 15 & $88.0 \pm 0.8^{\mathrm{abNS}}$ & $1450 \pm 9 \mathrm{~dB}$ & $942 \pm 7 \mathrm{~dB}$ & $508 \pm 7^{\mathrm{cB}}$ & $1886 \pm 9 \mathrm{~dB}$ & $944 \pm 2 \mathrm{~dB}$ & $5.7 \pm 0.8^{\mathrm{cB}}$ \\
\hline \multirow[t]{6}{*}{ WPI } & 5 & $87.0 \pm 0.5^{\mathrm{abNS}}$ & $1832 \pm 23^{b C}$ & $1094 \pm 30^{\text {bB }}$ & $738 \pm 10^{\text {ьв }}$ & $2170 \pm 36^{\mathrm{bB}}$ & $1076 \pm 60^{\mathrm{bNS}}$ & $6.1 \pm 0.1$ aNs \\
\hline & 10 & $86.7 \pm 0.1 \mathrm{bNS}$ & $1593 \pm 18^{\mathrm{cC}}$ & $951 \pm 18^{\mathrm{cC}}$ & $641 \pm 15^{\mathrm{cC}}$ & $1933 \pm 24^{\mathrm{cC}}$ & $982 \pm 23^{\mathrm{cB}}$ & $5.8 \pm 0.0^{\mathrm{bNS}}$ \\
\hline & 15 & $87.3 \pm 0.0^{\mathrm{abNS}}$ & $1374 \pm 31 \mathrm{dC}$ & $849 \pm 17 \mathrm{dC}$ & $525 \pm 14 \mathrm{~dB}$ & $1700 \pm 34 \mathrm{dC}$ & $851 \pm 17 \mathrm{dC}$ & $5.7 \pm 0.0^{\mathrm{bcAB}}$ \\
\hline & 20 & $87.2 \pm 0.0$ авв & $1153 \pm 35^{\mathrm{eB}}$ & $747 \pm 17^{\mathrm{ев}}$ & $406 \pm 18^{\text {ев }}$ & $1459 \pm 31^{\mathrm{eC}}$ & $712 \pm 15^{\mathrm{eC}}$ & $5.6 \pm 0.0^{\mathrm{cdNS}}$ \\
\hline & 25 & $87.5 \pm 0.5^{\mathrm{ab} A \mathrm{~B}}$ & $1165 \pm 53^{\mathrm{eB}}$ & $762 \pm 29^{\mathrm{eB}}$ & $403 \pm 24^{\mathrm{eB}}$ & $1465 \pm 63^{\text {ев }}$ & $704 \pm 34^{\mathrm{eB}}$ & $5.7 \pm 0.1^{\mathrm{bcdA}}$ \\
\hline & 30 & $88.6 \pm 1.3$ aNs & $925 \pm 41^{\mathrm{fB}}$ & $639 \pm 16^{\mathrm{fB}}$ & $286 \pm 24^{\mathrm{fB}}$ & $1205 \pm 27^{\mathrm{fB}}$ & $566 \pm 12^{\mathrm{fC}}$ & $5.5 \pm 0.2 \mathrm{dNS}$ \\
\hline
\end{tabular}

Averages \pm standard deviations. WF: wheat flour; PPI: pea protein isolate; SPI: soy protein isolate; WPI: whey protein isolate. Means with lowercase and different letters in the same column a for each isolate differ statistically from each other $(\mathrm{P} \leq 0.05)$. Averages with capital letters for the same replacement levels differ statistically from each other $(\mathrm{P} \leq 0.05)$. NS, ns: no significant.

\section{Conclusion}

Concerning empirical rheological properties, the addition of protein isolates to wheat flour caused a weakening of the dough (making it stickier and less elastic), except at a concentration of 5\% WPI, which caused an apparent strengthening. It is worth mentioning that PPI and SPI showed similar behavior, whereas WPI presented some distinct characteristics, such as decreased water absorption. Nevertheless, among the isolates, PPI proved to be the one that least interfered in the rheological of pure flour. In the analysis of pasting properties, a decrease in most parameters (except pasting temperature) was verified. And, although the behavior was similar, once again PPI was the one that least interfered. However, WPI proved to be more effective in decreasing setback, which could be related to an anti-staling effect that should be confirmed by baking tests.

Despite the changes due to the addition of other protein sources to wheat flour, their use for enriching products based on this ingredient can be suggested, indicating appropriate levels for each product. Addition of PPI and SPI up to $10 \%$, and of WPI up to $5 \%$, did not greatly modify dough viscoelastic profile, and would allow the use of these mixtures in the production of bread, for example. Notwithstanding, higher concentrations of these isolates interfered in the properties of the dough, making it possible to suggest their use for producing molded biscuits and cookies, for instance, in which the formation of a gluten network is not required. Even at lower concentrations, protein intake would already be improved, mainly by the increase in lysine.

\section{References}

American Association of Cereal Chemistry International - AACCI (2010). Approved methods of analysis (11st ed.). Saint Paul: AACC International.

Ammar, A. S., Salem, S. A., \& Badr, F. H. (2011). Rheological properties of wheat flour dough as affected by addition of whey and soy proteins. Pakistan Journal of Nutrition, 10(4), 302-306. http://dx.doi. org/10.3923/pjn.2011.302.306.

Ampe, C., Van Damme, J., Castro, A., Sampaio, M. J., Van Montagu, M., \& Vandekerckhove, J. (1986). The amino acid sequence of the $2 S$ sulphur-rich proteins from seeds of Brazil nut (Bertholletia excelsa HBK). European Journal of Biochemistry, 159(3), 597-604. http:// dx.doi.org/10.1111/j.1432-1033.1986.tb09926.x. PMid:3758080.

Brasil, Ministério da Agricultura, Pecuária e Abastecimento. (2005, June 2). Regulamento técnico de identidade e qualidade da farinha de trigo. (Instrução Normativa no 8 , de 2 de junho de 2005). Diário Oficial [da] República Federativa do Brasil.

Coutinho, L. A. A., Cerqueira, L. S., Rodrigues, A. V. S., Porto, C. P. M., \& Pierucci, A. P. T. R. (2014). Co-ingestion of carbohydrate and pea protein does not enhance muscle recovery after strenuous exercise. Revista de Nutrição, 27(3), 367-377. http://dx.doi.org/10.1590/141552732014000300010

Crockett, R., Ie, P., \& Vodovotz, Y. (2011). Effects of soy protein isolate and egg white solids on the physicochemical properties of gluten-free bread. Food Chemistry, 129(1), 84-91. http://dx.doi.org/10.1016/j. foodchem.2011.04.030.

Dhinda, F., Lakshmi, A. J., Prakash, J., \& Dasappa, I. (2012). Effect of ingredients on rheological, nutritional and quality characteristics of high protein, 
high fibre and low carbohydrate bread. Food and Bioprocess Technology, 5(8), 2998-3006. http://dx.doi.org/10.1007/s11947-011-0752-y.

Dobraszczyk, B. J. (1997). The rheological basis of dough stickiness. Journal of Texture Studies, 28(2), 139-162. http://dx.doi. org/10.1111/j.1745-4603.1997.tb00108.x.

Etzel, M. R. (2004). Manufacture and use of dairy protein fractions. The Journal of Nutrition, 134(4), 996S-1002S. http://dx.doi.org/10.1093/ jn/134.4.996S. PMid:15051860.

Foegeding, E. A., Luck, P., \& Vardhanabhuti, B. (2011). Whey protein products. In J. Fuquay, P. Fox, \& P. McSweeney (Eds.), The encyclopedia of dairy sciences (pp. 873-878). Oxford: Academic Press. http:// dx.doi.org/10.1016/B978-0-12-374407-4.00350-2.

Gani, A., Broadway, A. A., Ahmad, M., Ashwar, B. A., Wani, A. A., Wani, S. M., Masoodi, F. A., \& Khatkar, B. S. (2015). Effect of whey and casein protein hydrolysates on rheological, textural and sensory properties of cookies. Journal of Food Science and Technology, 52(9), 5718-5726. http:// dx.doi.org/10.1007/s13197-014-1649-3. PMid:26344985.

Gruber, P., Becker, W. M., \& Hofmann, T. (2005). Influence of the Maillard reaction on the allergenicity of $r$ Ara $h 2$, a recombinant major allergen from peanut (Arachis hypogaea), its major epitopes, and peanut agglutinin. Journal of Agricultural and Food Chemistry, 53(6), 2289-2296. http://dx.doi.org/10.1021/jf048398w. PMid:15769170.

Hagen, S. R., Frost, B., \& Augustin, J. (1989). Precolumn phenylisothiocyanate derivatization and liquid chromatography of amino acids in food. Journal - Association of Official Analytical Chemists, 72(6), 912-916. http://dx.doi.org/10.1093/jaoac/72.6.912. PMid:2592313.

Indrani, D., Prabhasankar, P., Rajiv, J., \& Rao, G. V. (2007). Influence of whey protein concentrate on the rheological characteristics of dough, microstructure and quality of unleavened flat bread (parotta). Food Research International, 40(10), 1254-1260. http:// dx.doi.org/10.1016/j.foodres.2007.08.005.

International Association for Cereal Science and Technology - ICC. (1996). Rapid pasting method using the Newport Rapid Visco Analyser. Wien: ICC Standard Methods.

Karaca, A. C., Low, N., \& Nickerson, M. (2011). Emulsifying properties of chickpea, faba bean, lentil and pea proteins produced by isoelectric precipitation and salt extraction. Food Research International, 44(9), 2742-2750. http://dx.doi.org/10.1016/j.foodres.2011.06.012.

Lam, A. C. Y., Warkentin, T. D., Tyler, R. T., \& Nickerson, M. T. (2017). Physicochemical and functional properties of protein isolates obtained from several pea cultivars. Cereal Chemistry, 94(1), 89-97. http:// dx.doi.org/10.1094/CCHEM-04-16-0097-FI.

Lucas, B., \& Sotelo, A. (1980). Effect of different alkalies, temperature, and hydrolysis times on tryptophan determination of pure proteins and of foods. Analytical Biochemistry, 109(1), 192-197. http://dx.doi. org/10.1016/0003-2697(80)90028-7. PMid:6894068.

Madenci, A. B., \& Bilgiçli, N. (2014). Effect of whey protein concentrate and buttermilk Powders on rheological properties of dough and Bread quality. Journal of Food Quality, 37(2), 117-124. http://dx.doi. org/10.1111/jfq.12077.

Mohsen, S. M., Fadel, H. H. M., Bekhit, M. A., Edris, A. E., \& Ahmed, M. Y. S. (2009). Effect of substitution of soy protein isolate on aroma volatiles, chemical composition and sensory quality of wheat cookies. International Journal of Food Science \& Technology, 44(9), 1705-1712. http://dx.doi.org/10.1111/j.1365-2621.2009.01978.x.

Onwulata, C. I., Tunick, M. H., \& Thomas-Gahring, A. E. (2014). Pasting and extrusion properties of mixed carbohydrate and whey protein isolate matrices. Journal of Food Processing and Preservation, 38(4), 1577-1591. http://dx.doi.org/10.1111/jfpp.12118.

Pereira, C. A. S., \& Oliveira, F. B. (2004). Soja, alimento e saúde: valor nutricional e preparo. Viçosa: Editora UFV.
Reinkensmeier, A., Bußler, S., Schlüter, O., Rohn, S., \& Rawel, H. M. (2015). Characterization of individual proteins in pea protein isolates and air classified samples. Food Research International, 76, 160-167. http://dx.doi.org/10.1016/j.foodres.2015.05.009.

Ribotta, P. D., Arnulphi, S. A., León, A. E., \& Añón, M. C. (2005). Effect of soybean addition on the rheological properties and breadmaking quality of wheat flour. Journal of the Science of Food and Agriculture, 85(11), 1889-1896. http://dx.doi.org/10.1002/jsfa.2191.

Rockland, L. B., \& Radke, T. M. (1981). Legume protein quality. Food Technology, 28, 79-82.

Saeed, M., \& Cheryan, M. (1988). Sunflower protein concentrates and isolates' low in polyphenols and phytate. Journal of Food Science, 53(4), 1127-1131. http://dx.doi.org/10.1111/j.1365-2621.1988.tb13545.x.

Schmiele, M. (2009). Caracterização das frações com diferentes granulometrias de milho dentado e duro e avaliação na qualidade de extrusados expandidos (Dissertação de mestrado). Universidade Estadual de Campinas, Campinas.

Schmiele, M., Araújo, T. L., Gurgueira, M. D., \& Chang, Y. K. (2015). Determinação da concentração de diferentes sistemas de solventes na solubilização de proteínas de análogo de carne. Ciência Rural, 45(6), 1120-1125. http://dx.doi.org/10.1590/0103-8478cr20131630.

Schmiele, M., Felisberto, M. H. F., Clerici, M. T. P. S., \& Chang, Y. K. (2017). Mixolab ${ }^{\text {tx }}$ for rheological evaluation of wheat flour partially replaced by soy protein hydrolysate and fructooligosaccharides for Bread production. Lebensmittel-Wissenschaft + Technologie, 76, 259-269. http://dx.doi.org/10.1016/j.lwt.2016.07.014.

Schmiele, M., Jaekel, L. Z., Patricio, S. M. C., Steel, C. J., \& Chang, Y. K. (2012). Rheological properties of wheat flour and quality characteristics of pan bread as modified by partial additions of wheat bran or whole grain wheat flour. International Journal of Food Science \& Technology, 47(10), 2141-2150. http://dx.doi.org/10.1111/j.1365-2621.2012.03081.x.

Singh, M., \& Mohamed, A. (2007). Influence of gluten-soy protein blends on the quality of reduced carbohydrates cookies. LebensmittelWissenschaft + Technologie, 40(2), 353-360. http://dx.doi.org/10.1016/j. lwt.2005.09.013.

Stone, A. K., Karalash, A., Tyler, R. T., Warkentin, T. D., \& Nickerson, M. T. (2014). Functional attributes of pea protein isolates prepared using different extraction methods and cultivars. Food Research International, 76, 31-38. http://dx.doi.org/10.1016/j.foodres.2014.11.017.

Sudha, M. L., Rajeswari, G., \& Rao, G. V. (2011). Influence of defatted soy flour and whey protein concentrate on dough rheological characteristics and quality of instant vermicelli. Journal of Texture Studies, 42(1), 72-80. http://dx.doi.org/10.1111/j.1745-4603.2010.00269.x.

Swanson, B. G. (1990). Pea and lentil protein extraction and functionality. Journal of the American Oil Chemists' Society, 67(5), 276-280. http:// dx.doi.org/10.1007/BF02539676.

Tang, X., \& Liu, J. (2017). A comparative study of partial replacement of wheat flour with whey and soy protein on rheological properties of dough and cookie quality. Journal of Food Quality, 2017, 2618020. http://dx.doi.org/10.1155/2017/2618020.

White, J. A., Hart, R. J., \& Fry, J. C. (1986). An evaluation of the Waters Pico-Tag system for the amino-acid analysis of food materials. Journal of Automatic Chemistry, 8(4), 170-177. http://dx.doi.org/10.1155/ S1463924686000330. PMid:18925132.

Zadow, J. G. (1981). Measurement of the effect of whey protein concentrates on fermenting dough by the Instron Tester. Australian Journal of Dairy Technology, 36, 56-59.

Ziegler, F. L. F., \& Sgarbieri, V. C. (2009). Caracterização químiconutricional de um isolado proteico de soro de leite, um hidrolisado de colágeno bovino e misturas dos dois produtos. Revista de Nutrição, 22(1), 61-70. http://dx.doi.org/10.1590/S1415-52732009000100006. 